\title{
Contaminated soil concrete blocks
}

\author{
A.C.J. de Korte \& H.J.H. Brouwers \\ University of Twente, Enschede, The Netherlands
}

\begin{abstract}
According to Dutch law the contaminated soil needs to be remediated or immobilised. The main focus in this article is the design of concrete blocks, containing contaminated soil, that are suitable for large production, financial feasible and meets all technical and environmental requirements. In order to make the design decision on the binder composition, binder demand and water demand needed to be made. These decisions depend on the contaminations present and their concentration. Two binder combinations were examined, namely slag cement with quicklime and slag cement with hemi-hydrate. The mixes with hemi-hydrate proved to be better for the immobilization of humus rich soils, having a good early strength development. Based on the present research, a concrete mix with a binder combination of $90 \%$ blast furnace cement and $10 \%$ hemihydrate, a binder-content of $305 \mathrm{~kg} / \mathrm{m}^{3}$ and water-binder factor of 0.667 gave the best results.
\end{abstract}

\section{INTRODUCTION}

In the Netherlands, there is a large demand for primary construction materials. At the same time, many locations in the Netherlands are contaminated and need to be remediated according to the national environmental laws (WBB, 1986) (BMD, 1993). Since the amendment to the National Waste Management plan in 2005, immobilization is considered to be equivalent to remediation of waste (LAP, 2005). Immobilization of contaminated soil can be a partial solution for both needs. Immobilization also fits the sustainable building concept, because waste materials are re-used, so less primary construction material is needed.

The Netherlands Building Material Degree (BMD, 1993), which applies to stony materials, distinguishes two categories of construction materials: shape retaining and non-shape retaining materials. The determination of the leaching, the leaching limits and the composition limits differ for these two categories. The successful production of a non-shape retaining building material using contaminiated dredging sludge and the binders slag cement and lime was presented by Brouwers et al. (2007). Shape-retaining materials are defined as sustainable shape-retaining and which have a volume of at least $50 \mathrm{~cm}^{3}$. Sustainable shaperetaining implies a limited weight loss of $30 \mathrm{gr} / \mathrm{m}^{2}$ during the diffusion test (BMD, 1993). An additional problem with the immobilization of soil is the possible presence of humus with the soil. Humus can retard the hydration of cement and can have a negative influence on the characteristics of a mix.

The immobilisates need to be able to replace products which are made from primary raw material.
Therefore, the immobilisates need to fulfil, besides the leaching limits, the same requirements as products based on primary materials. In this case, where a construction block is produced, at least a compressive strength of $25 \mathrm{~N} / \mathrm{mm}^{2}$ is required. In addition, the immobilisate needs to represent a financially feasible solution, which means that the profit on producing the immobilisate must be the same or better than that of the primary product. Furthermore, this production of the immobilisates should be possible on a large scale. So, financially feasible solutions and production on a large scale are both important criteria for the design of the mix.

The purpose of the present research is the development of financially feasible mixes for the immobilization of contaminated soil by producing a shaped construction materials using cement, lime and additives, such that mixes can be applied on a large scale in accordance with national law. This objective was furthered through theoretical and laboratory research.

The research consists of two parts: the main experiment and an additional experiment. The main experiment was focused on the immobilization of two soils.

\section{MATERIALS AND METHODS}

This section describes the used materials and methods.

\subsection{Materials}

Two soils were used within this research. The physical characteristics of both soils, henceforth named D- and 
Table 1. Physical and chemical characterization of soils.

\begin{tabular}{lll}
\hline Parameter & D-soil & J-soil \\
\hline Dry matter $(\mathrm{dm})$ & $94.8 \% \mathrm{~m} / \mathrm{m}$ & $63.6 \% \mathrm{~m} / \mathrm{m}$ \\
Organic matter $(\mathrm{H})$ & $2.4 \% \mathrm{dm}$ & $19.0 \% \mathrm{dm}$ \\
Lutum $(\mathrm{L})$ & $7.9 \% \mathrm{dm}$ & $2.4 \% \mathrm{dm}$ \\
CaCO3 & $1.6 \% \mathrm{dm}$ & $17.0 \% \mathrm{dm}$ \\
\hline
\end{tabular}

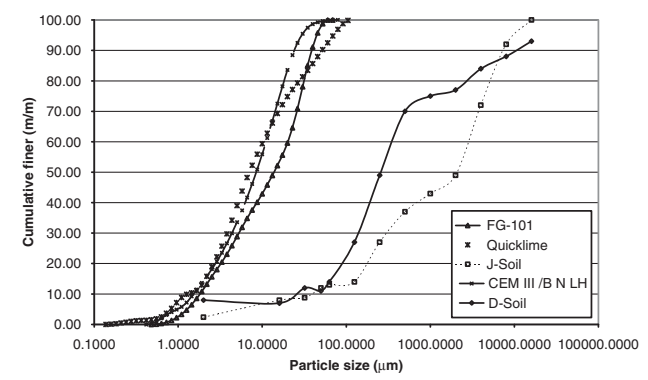

Figure 1. Particle size distribution of the applied soils and binders.

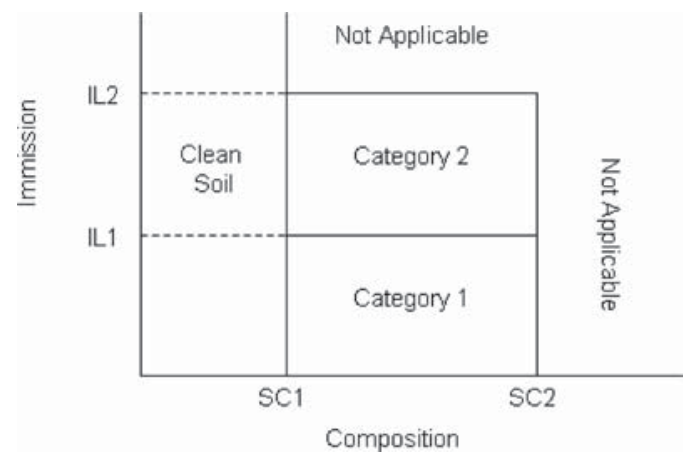

Figure 2. Classification of soil for the applicability as building material $(\mathrm{SC}=$ standard composition, $\mathrm{IL}=$ immision level).

$\mathrm{J}$-soil, are presented in Table 1 and the particle size distribution is presented in Figure 1. The D-soil is poor in humus, clay containing and sandy soil. The J-soil is a humus rich, clay containing and sandy soil and comes near to a peat soil. Both soils are common soil types in the Netherlands

Besides the physical characteristics, the environmental characteristics are important. In the Netherlands, soil is considered as a non-shaped material, while concrete is considered as a shaped material. The methods for the determination, when a material may be used, are different for both categories.

For non-shaped material, the leaching is determined using a column test, which is described in the standard NEN 7343. The BMD distinguishes four categories of non-shaped material, Figure 2 shows the distinction
Table 2. Standard strength development of CEM III/B 42.5 $\mathrm{NLH}$

\begin{tabular}{llrrr}
\hline Cement & \multicolumn{4}{l}{ Standard strength after N days } \\
\cline { 2 - 4 } & \multicolumn{2}{l}{$\mathrm{N} / \mathrm{mm}^{2}$} \\
\cline { 2 - 5 } CEM III/B 42,5 N LH & 1 & 2 & 7 & 28 \\
& - & 12 & 36 & 59 \\
\hline
\end{tabular}

between these categories. The distinction is made based on two parameters: immission and composition.

In this research a shaped material is produced. For a shaped material, the leaching is measured by the diffusion test, which is described in standard NEN 7345. For the mix design, only the composition is used, because the composition is a measure for the availability of heavy metals for leaching. Since the calculation methods differ for both categories of materials, a comparison of the immission of soil (non-shaped) and immission of product (shaped) is not possible. Therefore immission is very difficult to use for the mix design.

As can be seen from Figure 2, two limits (SC1 and $\mathrm{SC} 2$ ) are available for the composition of non-shaped material. Both limits depend on the physical parameters of the soil. This means that the two used soils have different limits. The D-soil only contains one pollutant, which renders it Not Applicable: cadmium is above the so called SC2-level. The J-soil contains arsenic, chromium, copper, lead, zinc and mineral oil levels that are above the SC2-level. These pollutants render this soil Not Applicable as well.

In this research a third soil is composed which consists of half J-soil and half 0-2 sand. This soil has a lower humus level and is used for the additional experiments in order to measure the effect of humus on the hydration and immobilization. This soil is named the $\mathrm{J} 1 / 2$-soil.

Besides the soils, some other materials were used like binders and aggregates. The used binders were slag cement (CEM III/B 42.5 N LH from ENCI), quick-lime (from Lhoist) and hemihydrate(FG-101 from Knauf). The strength development of the cement is shown in Table 2. Figure 1 shows the particle size distribution of the different binders besides the particle size distribution of the soils.

\subsection{Methods}

A description of the test procedures for slump-flow, V-funnel, capillary water absorption, compressive strength and tensile splitting strength, can be found in Brouwers \& Radix (2005).

The consistency of the mixes is assessed by the relative slump flow using the Abrams cone (concrete) or Haegermann cone (mortar). The relative slump $(\Gamma)$ is 
determined with Eq. (2), whereby $\mathrm{d}_{1}$ and $\mathrm{d}_{2}$ are the maximum diameters, rounded off at $5 \mathrm{~mm}$, and $\mathrm{d}_{0}$ is the base diameter of the Haegermann cone.

$\Gamma=\left(\frac{d_{i}}{d_{0}}\right)^{2}-1 \quad$ with $d_{i}=\frac{d_{1}+d_{2}}{2}$

Besides the consistency, also the required quantity of water for the cement and the filler can be determined by the slump flow. The spread flow test is a common way to assess the water demand of pastes and mortars. This yields a relation between relative slump flow $(\Gamma)$ and water/powder ratio $\left(\mathrm{V}_{\mathrm{w}} / \mathrm{V}_{\mathrm{p}}\right)$. The powders are defined here as all particles smaller than $125 \mu \mathrm{m}$. The test is executed analogously to Domone \& Wen (1997). Ordinary tap water is used as the mixing water in the present research. This relation is described by;

$\frac{V_{w}}{V_{p}}=E_{p} \cdot \Gamma+\beta_{p}$

This method was originally developed for powders only (Okamura \& Ouchi, 2003). But the same procedure can be applied on mortar mixes with the use of the same Heagermann cone. Besides the determination of relation between relative slump flow $(\Gamma)$ and water/powder ratio, it is also possible to do this for the water-/solid ratio. Solids means in this case the powders and sand in de mix.

Finally the leaching of the hardened product is measured by the diffusion test (NEN 7375). The cubes are places in 1 (in case mortar cubes) and 7 litres (in case of concrete cubes) of acid water of $\mathrm{pH} 4$. The acid water is replenished after $0.25,1,2.25,4,8,16,36$ and 64 days. This water is analysed on the concentration of heavy metals. From this leached amount the immission can be calculated according to NEN 7375 and BMD. Further details of the followed calculation procedure can be found in de Korte (2006).

\section{PREVIOUS RESEARCH}

In this section, previous research will be recapitulated. This information will serve as a basis for the new mix designs developed and tested here, presented in the next Section.

\subsection{The influence of contaminants on immobilisation}

The contaminants' characteristics influence the degree to which immobilization is possible. Arsenic, lead, chromium and cadmium are solvable in acid environments. Arsenic and lead are amorphous, which mean that they are soluble in both acidic and base environments. Immobilisates which are produced using cement have a high $\mathrm{pH}$. This means that heavy metals are soluble and available for leaching. The leaching behaviour strongly depends on the valence of the metal. Both arsenic and chromium have more than one valence. Chromium (III) is for instance easier to retain than chromium (VI) (Mattus \& Gilliam, 1994).

Heavy metals also influence the hydration of cement. Copper, lead and zinc will retard the hydration of cement (Mattus \& Gilliam, 1994). Chromium shortens the gel fibres and increases the matrix porosity (Palomo \& Palacios, 2003).

The way heavy metals are incorporated in the hardened product differs from case to case. Cadmium, zinc and arsenic can replace calcium within CSH (Pomies et al., 2001). Chromium and lead are absorbed within the CSH-binding, but nickel cannot be absorbed within the CSH binding (Bonen \& Sarkar, 1995). Chromium (III) can replace aluminium within the CAH-binding (Duchesne \& Laforest, 2004). The different binders have a different oxide composition and therefore they have a different level of bindings. This means that the most suitable binder can be selected based on the required bindings.

\subsection{Possible binder combinations}

In this section the feasible binder combinations are described. The first and most known binder is ordinary Portland cement (OPC). Portland cement is suitable for immobilization of most heavy metals. Pure blast furnace slag is more suitable for the immobilization of heavy metals in humus rich soils. The use of slags results in a lower porosity and permeability compared to the use of Portland cement. A lower porosity normally results in a lower level of leaching. However, a major disadvantage of the use of slag is the slower reaction rate. This reaction rate decreases further due to the presence of heavy metals and humic acid. Hence, an iniator could be needed when slags are deployed. The main reason is the absence of a calcium source within slag (Chen, 2007). Possible iniators are quicklime, anhydrite and hemi-hydrate. The advantage of the use of calcium sulphates is the possible formation of ettringite. Ettringite can fill the pores between the soil particles and so decrease the porosity and permeability. A lower porosity will result in a lower level of leaching (Mattus \& Gilliam, 1994).

Portland cement is also an initiator for slag. The combination of Portland cement and slag, i.e. slag blended cement, results in a higher compressive strength and better immobilization than when Portland cement is used only. The combination of Portland cement and slag has the same effect as when blast furnace slag cement is used. For instance, the combination of $25 \%$ Portland cement and $75 \%$ blast furnace 
slag has the same composition as many available blast furnace slag cements.

Another possible binder is pulverized fly ash (PFA), although it is less suitable than blast furnace slag. For the immobilisation of cadmium and copper, PFA is less suitable (Peysson et al., 2005). For chromium, PFA is completely unsuitable, because it appeared that no strength development took place at all (Palomo \& Palacios, 2003). PFA combined with Portland cement is suitable for the immobilization of copper but unsuitable for lead (Thevenin \& Pera, 1999). Besides, as PFA reacts slowly, the strength development is slow too. So fly ash can better not be used for the immobilization of heavy metals.

The combination of calcium sulfoaluminate cement (CSA) and hemihydrate can be used instead of blast furnace slag. In a ratio of 70/30 CSA/Hemihydrate it is suitable for all heavy metals except six valence chromium. For six valence chromium, a ratio of 80/20 is suitable. The combination of CSA with hemihydrate can result in the formation of ettringite. Ettringite can fill the pores between soil particles and therefore results in lower porosity and permeability, and also a lower level of leaching (Peysson et al, 2005). A disadvantage of the combination of CSA with hemihydrate is the introduction of more sulphate into the mix. Ettringite and gypsum are dissolved at low $\mathrm{pH}$ values, which results in the release of sulphate. The leaching of this sulphate is also regulated in the Building Material Decree. This problem also exists with the combination of blast furnace slag and hemihydrate. However, in the case of blast furnace slag cement and hemihydrate the problem is smaller due to a lower amount of sulphate in the binder.

\subsection{Required binder amount}

In this section, the determination of the amount of binder per $\mathrm{m}^{3}$ of concrete is described. An amount of $250 \mathrm{~kg}$ binder per $\mathrm{m}^{3}$ concrete mix is currently used for the production of concrete blocks by Dusseldorp groep. According to Axelsson et al (2002), between $100-200 \mathrm{~kg} / \mathrm{m}^{3}$ is needed for the immobilisation of mud, $150-250 \mathrm{~kg} / \mathrm{m}^{3}$ for peat and $70-200 \mathrm{~kg} / \mathrm{m}^{3}$ for hydraulic filling. Nijland et al. (2005) used $250 \mathrm{~kg} / \mathrm{m}^{3}$ for the immobilisation of contaminated Gorinchems clay. Based on these finding, here also a binder level of $250 \mathrm{~kg} / \mathrm{m}^{3}$ is included. The binder amount of $350 \mathrm{~kg}$ is selected as well to overcome the possible negative effects of heavy metals and humus. A binder amount of $500 \mathrm{~kg}$ is introduced to investigate if the addition of extra binder can neutralize the possible negative effect of large quantities of humus. Hence, in this research, binder amounts of 250,350 and $500 \mathrm{~kg} / \mathrm{m}^{3}$ are selected. These amounts correspond with 13.6, 21.9 and $26.7 \%(\mathrm{~m} / \mathrm{m})$ dry matter of D-soil. While the amount of $350 \mathrm{~kg}$ for the $\mathrm{J}$-soil corresponds to $38.4 \%$ and $500 \mathrm{~kg}$ with $58.2 \% \mathrm{dm}$.

\subsection{The composition of the binder}

This section summarizes possible binder combinations that will be used in this research. The first binder combination is slag cement and quicklime. This ratio is set to $90 / 10$. Brouwers et al. (2007) researched the immobilization on heavily contaminated (Class 4) dredging sludge. The ratio of 90/10 slag cement/quicklime gave good results. This finding is compatible with Janz and Johansson (2002), who point out that the optimal mix lies between 60-90\% slag cement and 40-10\% quicklime.

The choice of a ratio of $60 / 40$ slag cement/hemihydrate is based on the research of Huang (Huang, 1997). This ratio was confirmed by the research of Peysson et al. (2005). Peysson et al. (2005) indicated that $70 \% \mathrm{CSA}$ and $30 \%$ gypsum is a suitable binder for the immobilization of most heavy metals. CSA itself also contains calcium oxide and sulphate. Because of that, the levels of calcium and calcium sulphate are higher than at the same ratio of slag cement and hemi-hydrate. In order to compensate this, here the proportion of hemi-hydrate is increased to $40 \%$.

\section{EXPLORATORY TESTS}

As a preparation for the main-research, some exploratory tests were done to identify possible problems which could arise with the application of soil in concrete mixes. The main findings of the exploratory tests were;

- Both mixtures had a too low 28 days compressive strength, caused by a too high water/binder ratio and non-optimal particle size distribution

- The leaching of the mixtures was within the limits of the Dutch law. But the leaching of sulphates for the binder combination with gypsum approaches the limit. The leaching of heavy metals is better retained with blast furnace slag cement and quicklime.

\section{MORTAR EXPERIMENTS}

In this section the results of the experiments on mortar are described. The experiments on mortar are divided into two parts. The first part is the determination of the water demand for flowability, but at the same time the water content should be as low possible in order to achieve a high compressive strength and low leaching properties. The second part is the production of mortar cubes $\left(50 * 50 * 50 \mathrm{~mm}^{3}\right)$. The mix used for casting these mortar cubes was based on the results of the 
Table 3a. Composition D-mixes mortar cubes (in $\mathrm{kg} / \mathrm{m}^{3}$ ).

\begin{tabular}{|c|c|c|c|c|c|}
\hline & Present Mix & D-HK-250m & D-HG-250m & D-HK-350m & D-HK-500m \\
\hline Slag cement & & 195.3 & 130.2 & 303.3 & 360.5 \\
\hline Portland cement & 250 & & & & \\
\hline Quicklime & & 21,7 & & 33.7 & 40.1 \\
\hline Hemihydrate & & & 86,8 & & \\
\hline D soil (dry) & & 1590.2 & 1598.8 & 1538.2 & 1499.5 \\
\hline Sand & 1950 & 0 & 0 & 0 & 0 \\
\hline Water D soil & & 87.2 & 87.7 & 84.4 & 82.2 \\
\hline Superplastifizer & & 4.7 & 4.9 & 6.4 & 7.2 \\
\hline Mix water & 125 & 214.2 & 206.6 & 195.3 & 190.3 \\
\hline
\end{tabular}

Table 3b. Composition J-mixes mortar cubes (in $\mathrm{kg} / \mathrm{m}^{3}$ ).

\begin{tabular}{|c|c|c|c|c|c|}
\hline & J-HK-350m & J-HG-350m & $\mathrm{J}^{1} / 2-\mathrm{HK}-350 \mathrm{~m}$ & $\mathrm{~J}^{1} / 2-\mathrm{HG}-350 \mathrm{~m}$ & J-HK-500m \\
\hline $\begin{array}{l}\text { Slag cement } \\
\text { Portland cement }\end{array}$ & 298.4 & 198.2 & 408.4 & 259.7 & 431.7 \\
\hline Quick lime & 33.2 & & 45.0 & & 48.0 \\
\hline Hemihydrate & & 132.1 & & 173.1 & \\
\hline J soil(dry) & 863.2 & 854.4 & 590.7 & 559.7 & 823.8 \\
\hline $\begin{array}{l}\text { Water J soil } \\
\text { Sand 0-2 }\end{array}$ & 494.7 & 489.7 & $\begin{array}{l}338.5 \\
590.8\end{array}$ & $\begin{array}{l}320.8 \\
559.6\end{array}$ & 472.2 \\
\hline Sand + gravel & & & & & \\
\hline Superplastizer & 8.4 & 8.5 & 9.0 & 8.9 & 10.5 \\
\hline Mix water & 44.6 & 47.8 & 36.9 & 78.5 & 32.8 \\
\hline
\end{tabular}

water demand part. The compressive strength, capillary absorption and diffusion of these mortar cubes will be determined. The results of the main and additional experiment are incorporated in this section. Section 5.3 will address the main findings of the additional experiment.

\subsection{Water demand determination}

The water demand determination was carried out using the slump flow test for the mortar mix. This mortar mix includes binders, soil (fraction that passes the $4 \mathrm{~mm}$ sieve) and sand. The soil was sieved in order to make it possible to use a small mortar mixer. The $\mathrm{D}$-soil could be sieved wet, but for the J-soil this was not possible. The J-soil is therefore dried during 24 houres at 105 $+/-5^{\circ} \mathrm{C}$. Before using this soil for the mortar mixes, the amount of water evaporated during drying was readded, and mixed with the soil. These soil-water mixes stood for 30 minutes, so the soil could absorb the water. By doing so a wet soil could be simulated, which is closer to the practice since in practice a wet soil will be used in the immobilization process.

The mixes are displayed in Tables 3a, b. The slump flow was measured for different water/powder ratios $(\mathrm{m} / \mathrm{m})$ and with differed amounts of superplastizer (Glenium 51), based on the mass of powders in the mix. The mass of powders is the sum of all particles smaller than $125 \mu \mathrm{m}$ present in the mix. The function

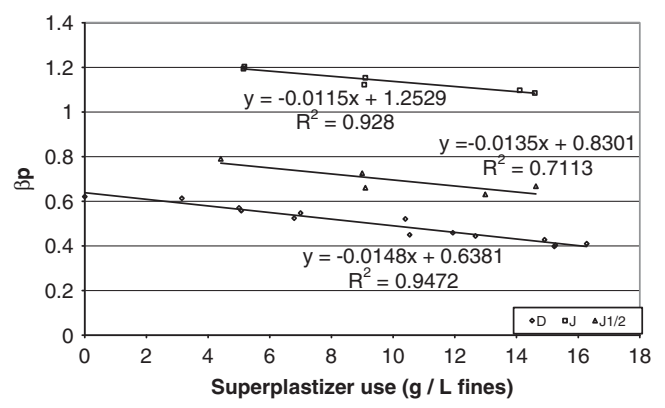

Figure 3. $\beta_{\mathrm{p}}$ versus SP dosage for D-soil $(215<$ binder $<$ $\left.400 \mathrm{~kg} / \mathrm{m}^{3}\right)$, J-Soil $\left(330<\right.$ binder $\left.<480 \mathrm{~kg} / \mathrm{m}^{3}\right)$ and $\mathrm{J} 1 \frac{1}{2}$-Soil $\left(430<\right.$ binder $\left.<455 \mathrm{~kg} / \mathrm{m}^{3}\right)$.

of a superplastizer is to reduce the quantity of water while maintaining the same workability.

The relative slump flow is plotted against the water/powder ratio to construct the spread-flow line. The relative slump flow is computed with Eq. (1) with $\mathrm{d}_{1}$ and $\mathrm{d}_{2}$ as the diameters of the slump flow and $\mathrm{d}_{0}$ the base diameter of the Haegermann cone.

The water demand $\left(\beta_{p}\right)$ of a mix is the interception point of the linear regression function based on these results (Okamura \& Ouchi, 2003), (see also Section 2.2 and Eq. (2)). In Figure 3, the water demands of mixes for different amounts of superplastizer are shown. 
Table 4a. Measured properties of mortar cubes D-soil.

\begin{tabular}{|c|c|c|c|c|c|}
\hline Property & & D-HK-250m & D-HG-250m & D-HK-350m & D-HK-500m \\
\hline Slump flow & {$[\mathrm{mm}]$} & $108-109$ & $107-108$ & $139-140$ & $107-110$ \\
\hline Relative Slumpflow $(\Gamma)$ & & 0.177 & 0.156 & 0.946 & 0.177 \\
\hline Compressive strength 7 days & {$\left[\mathrm{N} / \mathrm{mm}^{2}\right]$} & 1.91 & 3.09 & 8.31 & 10.05 \\
\hline Compressive strength 28 days & {$\left[\mathrm{N} / \mathrm{mm}^{2}\right]$} & 4.77 & 4.57 & 8.55 & 23.62 \\
\hline Density 7 days & {$\left[\mathrm{kg} / \mathrm{m}^{3}\right]$} & & & 1773 & 1941 \\
\hline Density 28 days & {$\left[\mathrm{kg} / \mathrm{m}^{3}\right]$} & 1647 & 1603 & 1761 & 1968 \\
\hline
\end{tabular}

Table 4b. Measured properties of mortar cubes J-Soil.

\begin{tabular}{lllllll}
\hline Property & & J-HK-350m & J-HG-350m & J1/2-HK-350m & J1/2-HG-350m & J-HK-500m \\
\hline Slump flow & {$[\mathrm{mm}]$} & $103-104$ & $100-103$ & $148-149$ & $109-110$ & $152-146$ \\
Relative Slumpflow $(\Gamma)$ & & 0.071 & 0.030 & 1.205 & 0.188 & 1.220 \\
Compressive strength 7 days & {$\left[\mathrm{N} / \mathrm{mm}^{2}\right]$} & - & 0.75 & 2,27 & 3,81 & - \\
Compressive strength 28 days & {$\left[\mathrm{N} / \mathrm{mm}^{2}\right]$} & - & - & - & - & 5.68 \\
Density 7 days & {$\left[\mathrm{kg} / \mathrm{m}^{3}\right]$} & 0.68 & 1.64 & 7.33 & 6.51 & 6.64 \\
Density 28 days & {$\left[\mathrm{kg} / \mathrm{m}^{3}\right]$} & 1640 & 1600 & 1868 & 1799 & 1707 \\
\hline
\end{tabular}

The different binder types all had their specific water demand. The mixes with slag cement and hemihydrate had a lower water demand $\left(\beta_{\mathrm{p}}\right.$ measured as water/powder ratio) than the mixes with slag cement and quicklime. Also, the mixes with $350 \mathrm{~kg}$ binder had a lower water demand $\left(\beta_{p}\right)$ than mixes with $250 \mathrm{~kg}$ binder. This lower water demand for higher binder amounts is partly caused by the chosen definition of water demand. Water demand is defined as the amount of water in de mix divided by the powder amount. Mixes with a higher binder content also have a higher powder content and hence, at same water content a lower water/powder ratio. But this effect can not explain the difference completely, because the total amount of water in the mixes is lower at higher binder contents. A possible explanation could be that the soil absorbed some of the mix water, so it is not available for enabling flowability. The mixes with higher binder content have namely a lower soil content. The mixes with $\mathrm{J}^{1} / 2$ had a lower water demand than the normal $\mathrm{J}$-mixes, which could be expected as $\mathrm{J} 1 / 2$ contains less fines. Section 6 contains a more detailed analysis of this effect/phenomenon.

\subsection{Mortar cubes results}

The mixes for mortar cubes were based on the results from the water demand study. A relative slump flow of 0.2 and a superplastizer use of $15 \mathrm{~g} / 1$ powder formed the two constraints used for the mix designs. The mix compositions are presented in Tables $3 \mathrm{a}, \mathrm{b}$.

The hardened mortar was tested for compressive strength, density, leaching and capillary absorption. The last two properties could only be measured for the
Table 5. Performance overview of binders on most important aspects

\begin{tabular}{lll}
\hline Aspect & Quicklime & Hemihydrate \\
\hline Early Strength & & + \\
Final Strength & + & \\
Leaching Sulphate & & - \\
Retaining heavy metals & + & ++ \\
Sustainable shape retaining & + & + \\
Humus neutralisation & & + \\
Legenda: ++ very suitable, + suitable, - unsuitable & \\
\hline
\end{tabular}

mixes containing slag cement and quicklime, because hemi-hydrate and gypsum readily dissolve when they come into contact with water.

The results of the experiments are presented in Tables $4 a, b$. A difference in the flowability was visible during the mixing. First, the mix was very dry and after a few minutes the mix became flowable. This time gap can be explained by the time the superplastizer needs to form a thin layer around the particles, which is a commonly known phenomenon.

In Table 5, a comparison between the quicklime and hemi-hydrate mixes is presented. The mixes containing quicklime had a lower early strength than comparable mixes with hemi-hydrate. The mix with quicklime could be crushed manually. These effects became very clear when the humus content of the soil was increased. The $500 \mathrm{~kg}$ variant of the J-soil with $19 \%$ humus could be crumbled manually after 1 day, but achieved a good compressive strength after 28 days. After 28 days, almost every mix with quicklime 
Table 6. Leaching results of mortar D-soil (in $\mathrm{mg} / \mathrm{m}^{2}$ ).

\begin{tabular}{lllll}
\hline & $\mathbf{i}_{\mathbf{m a x}}$ & $\mathbf{i}_{\mathbf{b v}}$ & & \\
\cline { 2 - 5 } & {$\left[m g / \mathrm{m}^{2}\right]$} & {$\left[m g / \mathrm{m}^{2}\right]$} & & \\
\cline { 2 - 5 } & & $\mathrm{D}-\mathrm{HK}-250 \mathrm{~m}$ & $\mathrm{D}-\mathrm{HK}-350 \mathrm{~m}$ & $\mathrm{~J}-\mathrm{HK}-500 \mathrm{~m}$ \\
\hline Sulphate & 100,000 & 30,352 & 52,080 & 10,158 \\
Cadmium & 12 & 0.04 & 0.05 & 0.07 \\
Chromium & 1500 & 0.04 & 0.04 & 1.40 \\
Copper & 540 & 0.11 & 0.10 & 3.00 \\
Nickel & 525 & 0.11 & 0.11 & 3.50 \\
Lead & 1275 & 0.45 & 0.45 & 1.40 \\
Zinc & 2100 & 0.37 & 0.38 & 1.40 \\
Cobalt & 300 & 0.07 & 0.07 & 3.50 \\
Arsenic & 435 & 0.84 & 0.84 & \\
\hline
\end{tabular}

had a higher compressive strength than the comparable mix with hemi-hydrate. In general, the compressive strength increased when the binder amount increased. This effect was partly caused by a decrease of the water/powder ratio, which has a direct relation on the compressive strength (Hunger \& Brouwers, 2006) and partly to the binder as such.

A high leaching of sulphate is considered negative due to the limitations for the leaching of sulphate according to the Building Material Degree. Mixes containing gypsum, hemi-hydrate and anhydrite have a high sulphate leaching level. This was already shown in the exploratory tests. The solubility of gypsum, hemihydrate and anhydrite is relatively high, which results in a high leaching of sulphate. This means that mixes with hemi-hydrate are less suitable than mixes with quicklime.

The retention capability of heavy metals is also important for the immobilisates. Hemihydrate mixes can retain heavy metals better than the quicklime mixes. But here it appeared that both hemi-hydrate and quicklime were suitable for retaining heavy metals within the immobilisates (Table 6). The metal leaching was less than $5 \%$ of the limits specified by the Building Material Decree. The possibility that leaching of sulphate was mask by the leaching of the heavy metals has to be taken into account.

Both the hemi-hydrate and quicklime mixes had a sustainable shape retention during exploratory tests. The tested quicklime mortar cubes also retained their shape during the diffusion test. The mixes with hemihydrate were not tested for this aspect, as they would dissolve.

\subsection{Additional experiment}

The mixes with hemi-hydrate appeared to be more suitable for immobilisation of humus rich soils. This effect becomes apparent at humus levels of 9.5 and $19 \%$.
Table 7. Comparison between different alternatives for immobilization of soil with high humus content.

\begin{tabular}{lll}
\hline & $\begin{array}{l}\text { Mix with } \\
0-2 \text { sand }\end{array}$ & $\begin{array}{l}\text { Extra } \\
\text { binder }\end{array}$ \\
\hline Compressive strength & + & + \\
Capillary water absorption & + & - \\
Financial feasibility & - & + \\
\hline
\end{tabular}

Legend: ++ very good, + good/better, - bad/less

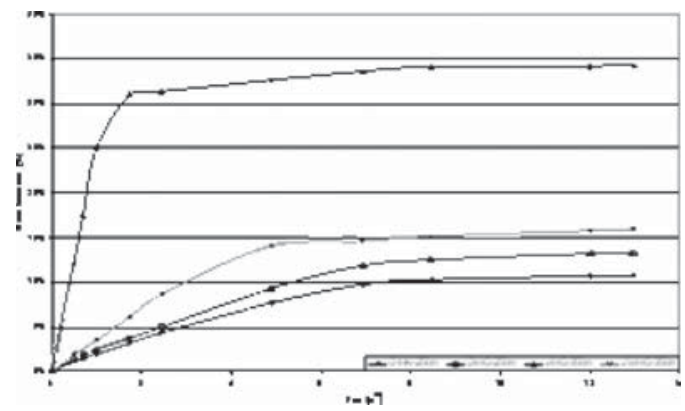

Figure 4. Capillary water absorption of the mortar cubes.

There was a threshold visible for the mixes with a high humus level. The compressive strength of the $350 \mathrm{~kg}$ variants is lower than $1.7 \mathrm{~N} / \mathrm{mm}^{2}$, while the $500 \mathrm{~kg}$ variant has a compressive strength of $6.7 \mathrm{~N} / \mathrm{mm}^{2}$. This was also the compressive strength for a mix containing half soil and half $0-2$ sand $\left(\mathrm{J}^{1} / 2\right)$ and $350 \mathrm{~kg}$ binder. So an alternative to reducing the humus content by mixing with sand was the use of more binder (Table 7). But humus also increases the capillary absorption, and this was not reduced by adding extra binder (Figure 4). From these capillary absorption tests it follows that capillary absorption increases when the level of humus is increased. From the financial point of view, adding extra binder is more desirable. This is because the soil 
Table 8. Specific densities of employed materials.

\begin{tabular}{ll}
\hline Component & Specific density \\
\hline Slag cement & $2950 \mathrm{~kg} / \mathrm{m}^{3}$ \\
Quicklime & $3345 \mathrm{~kg} / \mathrm{m}^{3}$ \\
Hemihydrate & $2700 \mathrm{~kg} / \mathrm{m}^{3}$ \\
D-soil & $2736 \mathrm{~kg} / \mathrm{m}^{3}$ \\
J-soil & $2679 \mathrm{~kg} / \mathrm{m}^{3}$ \\
Sand & $2650 \mathrm{~kg} / \mathrm{m}^{3}$ \\
Organic Matter & $1480 \mathrm{~kg} / \mathrm{m}^{3}$ \\
Mineral fraction & $2700 \mathrm{~kg} / \mathrm{m}^{3}$ \\
\hline
\end{tabular}

used in the mix does not need to be remediated, which generates revenues as remediation costs of soil can be avoided. By the application of the soil in the mix, there is no need for this remediation, so the saved cost of remediation can be seen a revenue. On the other hand, the addition of sand will lead to extra costs.

\section{ANALYSIS OF THE WATER DEMAND}

In Section 5.1, it was observed that the water demand of a mix decrease when the binder contents increase. This is contrary to what would be expected, namely that a higher powder content results in a higher water demand. A possible explanation could be that the soil was finer than binder, but this was not the case (Figure 1). In this section the relationship between water demand and the properties of the mixes is examined in more detail.

\subsection{Spread-flow analysis}

As discussed in Section 2, there is a relation between relative slump flow $(\Gamma)$ and water-/solid. The $\beta_{p}$ of the different mixes at different amount of superplastizer (SP) is shown in Figure 3. Having a closer look at Figure 3 , it can be noticed that the $\beta_{\mathrm{p}}$ of three soils result each in one line independently of the used mix design, which differs in amount of binder and binder combination. It appears that for each soil $\beta_{\mathrm{p}}$ depends linearly on the applied superplastizer dosage only.

\subsection{Void fraction}

For every soil a spread-flow line can be drawn. In order to analyse the lines the soil volume in the calculation is splitted into mineral part and organic matter, since these two parts have a different specific density. The mineral phase has a density between 2650 and $2750 \mathrm{~kg} / \mathrm{m}^{3}$, while organic matter has a density of $1480 \mathrm{~kg} / \mathrm{m}^{3}$. Table 8 shows the used specific densities for the calculation.

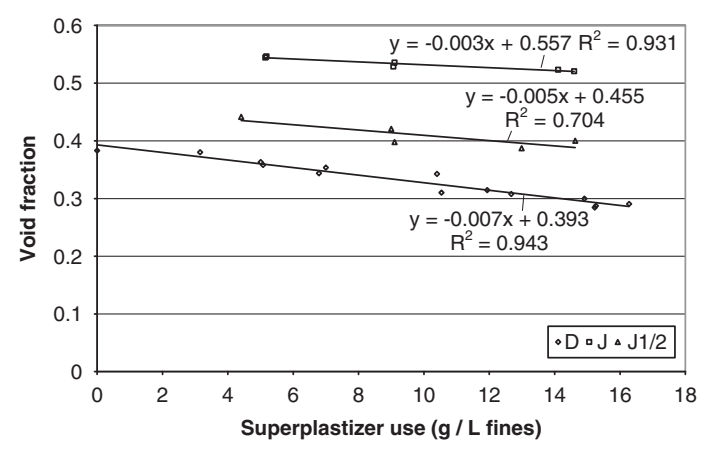

Figure 5. Void fraction versus SP dosage for the three employed soils.

It is also possible to assess the void fraction based on the $\beta_{\mathrm{p}}$ of the mixes. According to Brouwers and Radix (2005) this can be done according to Eq. (3).

$\phi_{\text {water }}(\Gamma=0)=\frac{V_{w}}{V_{\text {total }}}=\frac{V_{w}}{V_{w}+V_{s}}=\frac{\beta_{p}}{\beta_{p}+1}$

In which $\beta_{\mathrm{p}}$ is the interception of the spread flow line with the abscissa. It appears that for each soil the void fraction depends linearly on the applied superplastizer dosage. This is shown in Figure 5. For the D-soil this relation reads:

$\beta_{p}=-4.6 \cdot 10^{-3} \cdot \mathrm{SP}+0.46$

With SP in grams per liter fines

\subsection{Particle packing theory}

The packing of a granular mix is closely related to the particle size distribution. Continuously graded granular mixtures are often based on the Fuller parabola. The cumulative finer fraction is given as

$F(d)=\left(\frac{d}{d_{\max }}\right)^{0.5}$

Where $d$ is the sieve term and $d_{\max }$ represents the maximum sieve size (i.e. where $100 \%$ passing takes place). The introduction of a distribution modulus $\mathrm{q}$ by Andreasen and Andersen and a minimum particle size by Funk and Dinger (1994) led to an alternative equation, which reads as follows

$F(d)=\frac{d^{q}-d_{\min }^{q}}{d_{\max }^{q}-d_{\min }^{q}}$

It is believed that values of $q$ that range from 0 to 0.28 , lead to optimum packing (Hunger $\&$ Brouwers, 


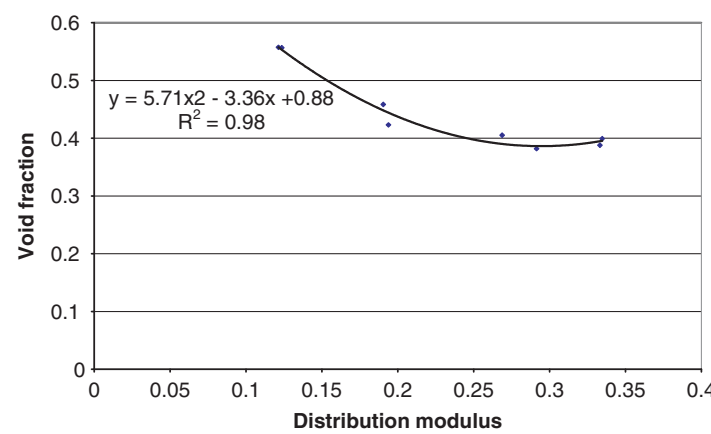

Figure 6. Derrived void fraction $\left(\beta_{\mathfrak{p}} /\left(\beta_{\mathrm{p}}-1\right)\right)$ and distribution modulus at $\Gamma=0$ and $\mathrm{SP}=0$.

2006). Hummel (1959) mentioned an optimum distribution modulus of 0.4 for round shaped aggregates and 0.3 for more angular shape aggregates. According to Brouwers (2006) several researchers refer to a distribution modulus of 0.37 for spatial grain distribution in order to obtain optimal packing and therefore minimum void fraction.

Using the particle size distribution of the mixes, the distribution modulus is assessed using fitting minimizing the sum of the squares of the residuals (RSS).

The distribution moduli is calculated for all mixes, for which holds $\mathrm{d}_{\max }=2.8 \mathrm{~mm}$ and $\mathrm{d}_{\min }=1 \mu \mathrm{m}$ for all solids. The distribution modulus versus the void fraction is shown in Figure 6. The relation between both characteristics can be described according to a quadratic function. The void fraction is minimal at a distribution modulus of about 0.3 . This is line with the range which is mentioned by previous authors (Hummel, 1959; Hunger \& Brouwers, 2006; Brouwers, 2006).

\subsection{Prelimary conclusions}

It is found that there is a linear relationship between superplastizer content and void fraction/packing for each soil depending for every relative slump flow, independent from the amount of binder and the binder composition. Furthermore, it is concluded that;

- The finer the mix, the higher the water demand and, because of this higher water demand, a higher void fraction.

- The $\mathrm{D}, \mathrm{J}$ and $\mathrm{J}^{1} 12$ mixes have a distribution modulus of a proximally $0.3,0.1$ and 0.2 .

- According to measurements a distribution modulus of 0.29 would minimize the void fraction. This is in line with the volume mentioned by previous authors (Hummel 1959; Brouwers 2006; Hunger \& Brouwers 2006).
- Superplastizer additions reduces linearly water demand of the mixes.

- The amount of binder showed a limited effect on the water demand within one soil. But the variance in amount of binder, used in this research, was limited, so the conclusion can be different when a binder amount differs substantially. The amount of binder used here is in range with the amounts used in practice.

Furthermore, the relationship between the SP dependency lines of the different soils is investigated. This relationship is typical for each soil on which property this depends is so far unknown. From the present research we could exclude dry matter, organic matter, lutum and $\mathrm{CaCO}_{3}$.

\section{CONCRETE MIX RESULTS}

The results of the mortar research were used for the preparation of the concrete mixes. In this part of the research, only D-Soil is used. A combination slag cement and quicklime forms the basis of the mixes. This binder combination performed well on all aspects during the mortar tests and does not have major drawbacks. Better results are to be expected from this combination compared to the binder combination slag cement with hemi-hydrate, for instance in regard to leaching (Sections 4 and 5).

Concrete is distinct from mortar because of the presence of bigger aggregates. The concrete mix consisted of 70-75\% mortar and 25-30\% coarse aggregates (Brouwers \& Radix, 2005). The concrete mixes are based on the mortar mixes D-HK-350m and D-HK-500m (Tables 3a, b).

Based on these two mix definitions, a preliminary mix was designed. This mix was optimized to meet two objectives. The first objective was the optimisation of the particle size distribution. This means a minimization of the sum of absolute deviations from the modified Andreasen and Andersen line with $\mathrm{q}=0.35$, $\mathrm{d}_{\min }=1 \mu \mathrm{m}$ and $\mathrm{d}_{\max }=16 \mathrm{~mm}$. The second target was to design a mix which is more cost effective than the present one.

Table 9 shows the composition of the final mixes. In Figure 7, the particle size distribution of the final mixes is shown. These mixes were selected (out of a number of possible mixes) because they had an acceptable deviation from target function (the modified AA-line) and lowest costs.

\subsection{Tests on fresh concrete}

The fresh concrete tests can be divided into slump flow and V-funnel tests. Two batches were made of each mix. The results of these tests are presented in Table 10. The 
mixes were designed for a relative slump flow of 0.2 . The relative slump flow and V-Funnel time differed considerably between the batches. The second batch of D-HK-500e was almost self-compacting, whereas the first batch was completely unflowable, this is due to fluctuations in the soil composition. These differences can be explained by the heterogeneity of the soil. For instance the amount of powder (all particles smaller than $125 \mu \mathrm{m}$ ) in the soil differs, resulting in a change in the water/powder ratio and the superplastizer content on powder. But differences in the sulphate level can also result in a different flowablity and workability. Fluctuations in the flowablility and workability of a mix can cause problems, when the mix is used in a production line. A solution for this problem is homogenizing of the soil prior to treatment, in order to reduce fluctuations in the composition of the soil and so fluctuations in the flowability and workability.

Table 9. Mix design final mixtures.

\begin{tabular}{lccc}
\hline & & D-HK-350e & D-HK-500e \\
\hline Slag cement & $\mathrm{kg} / \mathrm{m}^{3}$ & 209.5 & 274.9 \\
Quick lime & $\mathrm{kg} / \mathrm{m}^{3}$ & 23.3 & 30.6 \\
Hemihydrate & $\mathrm{kg} / \mathrm{m}^{3}$ & & \\
Dry DD ISM soil & $\mathrm{kg} / \mathrm{m}^{3}$ & 1104.0 & 1143.7 \\
Water DD ISM soil & $\mathrm{kg} / \mathrm{m}^{3}$ & 60.6 & 62.7 \\
Gravel 4-16 & $\mathrm{kg} / \mathrm{m}^{3}$ & 740.7 & 621.8 \\
Water Extra & $\mathrm{kg} / \mathrm{m}^{3}$ & 138.0 & 141.2 \\
SP-solution & $\mathrm{kg} / \mathrm{m}^{3}$ & 4.4 & 5.4 \\
\hline
\end{tabular}

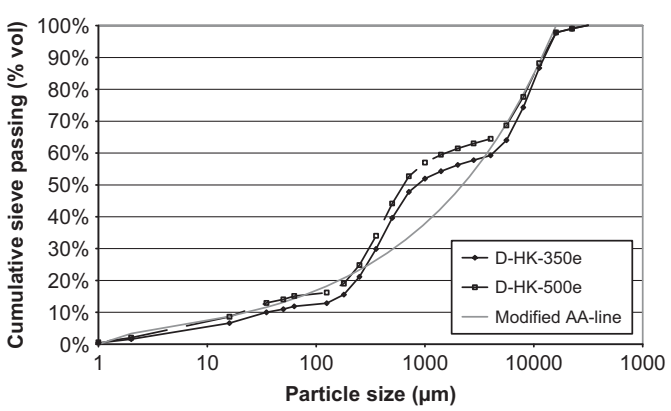

Figure 7. Cumulative finer function of final mixes $(q=$ $0.35, \mathrm{~d}_{\min }=1 \mu \mathrm{m}$ and $\mathrm{d}_{\max }=16 \mathrm{~mm}$ )

\subsection{Results on hardened concrete}

This section deals with the results of the hardened concrete tests, which can be divided into compressive strength, flexural strength, density, capillary absorption and leaching.

The 28 days compressive strength of the D-HK$350 \mathrm{e}$ mix did not fulfil the requirement of $25 \mathrm{~N} / \mathrm{mm}^{2}$, but D-HK-500e did fulfil this requirement. The measured compressive strength values were lower than the expected values based on general equations for the relation between compressive strength and the water/cement ratio. The compressive strength $\left(f_{c}\right)$ of a concrete, with an uncertainty up to $5 \mathrm{~N} / \mathrm{mm}^{2}$, can be assessed by

$f_{c}^{\prime}=\alpha N_{n}+\frac{\beta}{w c f}-\gamma$

The $\alpha, \beta$ and $\gamma$ in Eq. (7) are depending on the cement that is used. For slag cement this value are $0.75,18$ and 30 (ENCI, 2006). The $\mathrm{N}_{\mathrm{n}}$ is the standard strength of the used cement after $\mathrm{N}$ days. In Table 2 the standard strength of the used slag cement (CEM III/B 42,5 N LH) is shown.

The flexural strength of the mixes was between 1.5 and $2.7 \mathrm{~N} / \mathrm{mm}^{2}$. These values were in line with the expectations for the flexural strength based on the measured compressive strength.

The density of the mixes was lower than the expected value. This can mean a higher air content of the mixes than expected. The air content can be calculated from the measured and calculated densities (Table 11). For D-HK-350e follows an air content of $9.2 \%$ and for D-HK-500e $4.2 \%$

The capillary absorption of both mixes was lower than the requirement for self compacting concretes

Table 11. Density and air content of final mixtures.

\begin{tabular}{|c|c|c|c|c|}
\hline & \multicolumn{2}{|c|}{ Mix design } & \multicolumn{2}{|c|}{ Measured } \\
\hline & Density & $\begin{array}{l}\text { Air } \\
\text { content }\end{array}$ & Density & $\begin{array}{l}\text { Air content } \\
\text { (calculated) }\end{array}$ \\
\hline & $\mathrm{kg} / \mathrm{m}^{3}$ & $\% \mathrm{~V} / \mathrm{V}$ & $\mathrm{kg} / \mathrm{m}^{3}$ & $\% \mathrm{~V} / \mathrm{V}$ \\
\hline D-HK-350e & 2280 & 1 & 2093 & 9.2 \\
\hline D-HK-500e & 2280 & 1 & 2206 & 4.2 \\
\hline
\end{tabular}

Table 10. Results fresh concrete of the final concrete mixtures.

\begin{tabular}{|c|c|c|c|c|c|}
\hline & & $\begin{array}{l}\text { D-HK-350e } \\
\text { Batch } 1\end{array}$ & Batch 2 & $\begin{array}{l}\text { D-HK-500e } \\
\text { Batch } 1\end{array}$ & Batch 2 \\
\hline Slump flow & $\mathrm{mm}$ & $280-280$ & $220-220$ & $200-200$ & $510-520$ \\
\hline Relative Slump flow & & 0.96 & 0.21 & 0 & 5.63 \\
\hline V-Funnel & Sec. & $13-14$ & - & - & $15-13$ \\
\hline V-Funnel after $5 \mathrm{~min}$ & Sec. & $25 \mathrm{sec}$. & - & - & 16 \\
\hline
\end{tabular}


(less than $3 \mathrm{~mm} / \mathrm{h}^{0.5}$ ). D-HK-350e had a sorptionindex of $0.77 \mathrm{~mm} / \mathrm{h}^{0.5}$ and D-HK-500e had a sorptionindex of $1.21 \mathrm{~mm} / \mathrm{h}^{0.5}$.

The leaching of final mixes was very low compared to the limits of the BMD. In Table 12, the results of the test are displayed for D-HK-350e. The mixes fulfil the requirements of the BMD regarding leaching.

\section{CONCLUSIONS}

In this section, some conclusions are presented based on the research. The research consisted of a main experiment (Sections 4, 5.2 and 7) and an additional experiment (Section 5.3). First, the conclusions of the main experiment will be given and next the conclusions of the additional experiment will be described.

\subsection{Main experiment}

The results of the experiments have been examined for their financial feasibility, feasibility for production on large scale, shape retaining and strength. The following conclusions can be drawn;

- All mixes within the experiment were more cost effective than the current mixes with primary material.

- The mixes are suitable for production of immobilisates on large scale. The design of these real mixes has been adapted to the use of wet soil, instead of the dried material within the 'normal' laboratorium concrete production.

- The leaching of the mixes containing D-soil was tested according to the limitations of the Building Material Decree i.e. the diffusion test. The leaching of sulphate was near the limit for the mixes with hemi-hydrate during pre-research, due to the solving of gypsum when in contact with water.

- The J and D mixes were sustainable shape retaining. This means that the products can categorised

Table 12. Leaching of D-HK-350e.

\begin{tabular}{lll}
\hline & Measured immission & Maximum Immission \\
\cline { 2 - 3 } & $\mathrm{mg} / \mathrm{m}^{2}$ & $\mathrm{mg} / \mathrm{m}^{2}$ \\
\hline Sulphate & 3,171 & 100,000 \\
Cadmium & 0.04 & 12 \\
Chromium & 0.16 & 1500 \\
Copper & 0.08 & 540 \\
Nickel & 0.11 & 525 \\
Lead & 0.42 & 1275 \\
Zinc & 0.35 & 2100 \\
Cobalt & 0.06 & 300 \\
Arsenic & 0.84 & 435 \\
\hline
\end{tabular}

as a shaped material, which also implies that the diffusion (leaching) tests are indeed applicable.

- The strength of the final mix D-HK-500e was higher then the required compressive strength of $25 \mathrm{~N} / \mathrm{mm}^{2}$. The other mixes had a compressive strength of less than $25 \mathrm{~N} / \mathrm{mm}^{2}$. When a slightly lower compressive strength is acceptable, e.q. $20 \mathrm{~N} / \mathrm{mm}^{2}$, then already $350 \mathrm{~kg} / \mathrm{m}^{3}$ would have been sufficient.

Given these results, the final mixes of D soil, quicklime and slag cement (500 kg binder) fulfilled all the objectives. So the objective of the main experiment fulfilled both the technical and financial requirements.

\subsection{Additional experiment}

Humus strongly influences the hydration of cement. The mixes with hemi-hydrate were more suitable for the immobilization of humus rich soils. This was due to the better strength development of these mixes compared to mixes containing quicklime.

Two possible ways to reduce the effects of humus were considered during this research. The first method is the mixing of J-soil with $0-2$ sand to achieve a soil with a reduced humus level. The second method is the use of more binder.

Given the results, it seems that it is not possible to immobilize soil with a humus content of $19 \%$ with $350 \mathrm{~kg} / \mathrm{m}^{3}$ binder only. Based on the present research, two possible solutions are available to immobilize such soils. The first method is the reduction of humus content by replacing half of the soil with $0-2$ sand. But from a financial point of view, it is more attractive to increase the proportion of binder. The increase to $500 \mathrm{~kg} / \mathrm{m}^{3}$ of binder is a way to achieve the required compressive strength, without reduced the high capillary absorption, which is a result of the present of humus.

\section{ACKNOWLEDGEMENTS}

The authors would like to thank Ir. S.J. Dijkmans from Jaartsveld Groen en Milieu (Steenbergen, The Netherlands) and Ing. E.M.H. Schildkamp from Dusseldorp Groep (Lichtenvoorde, The Netherlands) for providing the soils, their practical advice and providing the chemical and leaching tests. This research was financially supported by the Delta Marine Consultants, Civil Engineering Division of the DirectorateGeneral for Public Works and Water Management, Jaartsveld Groen en Milieu, Senter-Novem Soil+, Rokramix, Betoncentrale Twenthe, Betonmortelcentrale Flevoland, Graniet-Import Benelux, Kijlstra Beton, Struyk Verwo Groep, Hülskens, Insulinde Recycling \& Milieu, Dusseldorp Groep, Eerland Recycling Services and ENCI. 


\section{REFERENCES}

Axelsson, K., Johansson, S., \& Andersson, R. (2002). Stabilization of organic soils by cement and pozzolanic reactions-feasibility study. Swedish Deep Stabilization Research Center Rep. No, 3 .

BMC. (2002). Aanvulling brl 1801, aanvulling op de nationale beoordelingsrichtlijn betonmortel (brl 1801), hoogvloeibare, verdichtingsarme en zelfverdichtende betonmortel. Gouda, The Netherlands: Certificatie Instelling Stichting BMC.

BMD. (1993). Bouwstoffenbesluit (Building Material Degree). from http://www.wetten.overheid.nl

Bonen, D., \& Sarkar, S. L. (1995). The effects of simulated environmental attack on immobilization of heavy metals doped in cement-based materials. Journal of Hazardous Materials, 40(3), 321-335.

Brouwers, H. J. H. (2006). Particle-size distribution and packing fraction of geometric random packings. Physical Review E, 74, 031309

Brouwers, H. J. H., Augustijn, D. C. M., Krikke, B., \& Honders, A. (2007). Use of cement and lime to accelerate ripening and immobilize contaminated dredging sludge. Journal of Hazardous Materials, 145(1), 8-16.

Brouwers, H. J. H., \& Radix, H. J. (2005). Self-compacting concrete: Theoretical and experimental study. Cement and Concrete Research, 35(11), 2116-2136.

Chen, W. (2007). Hydration of slag cement: Theory, modelling and application. University of Twente, Enschede, The Netherlands.

CUR. (2002). Cur-aanbeveling 93, zelfverdichtende beton. Gouda, The Netherlands: Stichting CUR

de Korte, A. C. J. (2006). Koude immobilisatie van verontreinigde grond; koude anorganische immobilisatie van verontreinigde grond met behulp van cement, kalk en gips. Master Thesis, University of Twente, Enschede.

Domone, P., \& HsiWen, C. (1997). Testing of binders for high performance concrete. Cement and Concrete Research, 27(8), 1141-1147.

Duchesne, J., \& Laforest, G. (2004). Evaluation of the degree of $\mathrm{Cr}$ ions immobilization by different binders. Cement and Concrete Research, 34(7), 1173-1177.

ENCI. (2006). Productinformation of slag cement 42,5 n. 's Hertogenbosch, the Netherlands: ENCI.

Funk, J. E., \& Dinger, D. R. (1994). Predictive process control of crowded particulate suspension, applied to ceramic manufacturing: Kluwer Academic Press.
Huang, X. (1997). On suibatility of stabilizer based on chemical analysis of the liquid from stabilized soil. Proceedings Fourteenth international conference on soil mechanics and foundation engineering, Hamburg, Published by A.A. Balkema, Rotterdam/Brookshield. 1613-1616.

Hummel, A. (1959). Das beton-abc; ein lehrbuch (12th ed.). Berlin: Verlag von Wilhelm Ernst \& Sohn.

Hunger, M., \& Brouwers, H. J. H. (2006). Development of self-compacting eco-concrete. Proceedings 16th IBausil, International Conference on Building Materials (Internationale Baustofftagung), Weimar, 2-0189-2-0198, Ed. H.B. Fischer, F.A. Finger-Institut für Baustoffkunde, Weimar, Germany.

Janz, M., \& Johansson, S. E. (2002). The function of different binding agents in deep stabilization. Swedish Deep Stabilization Research Center, Linkoping: SGI, 9.

LAP. (2005). Landelijk afvalbeheer plan 2002-2012. from http://www.wetten.overheid.nl

Mattus, C. H., \& Gilliam, T. M. (1994). A literature review of mixed waste components: Sensitivities and effects upon solidification/stabilization in cemnet-based matrices. Tennessee, US: Oak Ridge National Laboratory.

Nijland, T. G., van der Zon, W. H., Pachen, H. M. A., \& van Hille, T. (2005). Grondstabilisatie met hoogovencement: Verharding en duurzaamheid; stabilisatie voor de boortunnel van randstadrail. Geotechniek(Oktober), 44-52.

Okamura,H., \& Ouchi, M. (2003). Self-compacting concrete. Journal of Advanced Concrete Technology, 1(1), 5-15.

Palomo, A., \& Palacios, M. (2003). Alkali-activated cementitious materials: Alternative matrices for the immobilisation of hazardous wastes: Part ii. Stabilisation of chromium and lead. Cement and Concrete Research, 33(2), 289-295.

Peysson, S., Pera, J., \& Chabannet, M. (2005). Immobilization of heavy metals by calcium sulfoaluminate cement. Cement and Concrete Research, 35(12), 2261-2270.

Pomies, M.-P., Lequeux, N., \& Boch, P. (2001). Speciation of cadmium in cement: Part i. Cd2+ uptake by c-s-h. Cement and Concrete Research, 31(4), 563-569.

Thevenin, G., \& Pera, J. (1999). Interactions between lead and different binders. Cement and Concrete Research, 29(10), 1605-1610.

WBB. (1986). Wet bodembescherming. from http://www. wetten.overheid.nl 